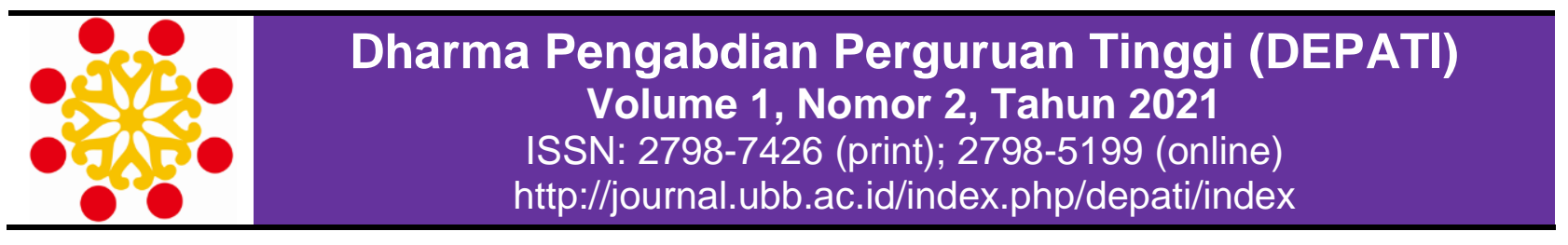

\title{
PELATIHAN PEMASARAN BERBASIS ONLINE DAN MEDIA SOSIAL KEPADA STAFF KELURAHAN JABUNGAN KECAMATAN BANYUMANIK KOTA SEMARANG PROVINSI JAWA TENGAH
}

\author{
Sukma N. Ardini*), Suwandi, A. B. Prabowo K. A., Siti Lestari, dan M. F. Darmaputra \\ Universitas PGRI Semarang \\ *E-mail korespondensi: sukmanurardini@upgris.ac.id
}

\begin{abstract}
Info Artikel: Abstract
Dikirim:

27 September

2021

Revisi:

5 November

2021

Diterima:

28 November

2021

Kata Kunci:

Pelatihan,

strategi,

pemasaran,

online, media

sosial

The results of the survey conducted by a team of Universitas PGRI Semarang in January 2018 showed that Kelurahan Jabungan Semarang has great local potential that is (1) designated as an empon-empon thematic village, (2) has a tourist attraction of Bukit Panji Laras, (3) ) has the potential of processed food products, but the problem of this village is the less awareness of the local government and the society. They do not realize that the potential of their village needs to be known by the public. Therefore, the team Universitas PGRI Semarang provides solutions through community service programs, especially those related to online-based marketing and social media, by applying problem identification, training program, mentoring program, and monitoring and evaluation program. The keynote speaker of this program is Mr. Andi Priyolistiyono, S. Kom, M.Kom, an online marketing expert who collaborates with the team who are also experts and successful businessmen. The focus of this program is online marketing and social media for food products made by the local society in Kelurahan Jabungan. The team facilitates this training with producers who have market shares, Madhang.id. The training results show that the participants can apply the training materials very well. Their products have been displayed at Madhang.id.
\end{abstract}

\begin{abstract}
Abstrak
Hasil survei yang dilakukan oleh tim pengabdian Universitas PGRI Semarang pada bulan Januari 2018 menunjukkan bahwa Kelurahan Jabungan Kota Semarang memiliki potensi lokal yang melimpah yaitu (1) ditunjuk sebagai kampung tematik empon-empon, (2) memiliki daya tarik wisata Bukit Panji Laras, (3) memiliki potensi produk olahan makanan. Namun permasalahan yang ada di kelurahan ini adalah kurangnya kesadaran pemerintahan desa dan warga bahwasanya tidak semua orang di luar sana mengenal potensi desa mereka sehingga perlu adanya publikasi pada masyarakat luas. Oleh karena itu, tim pengabdian memberikan solusi melalui program pengabdian masyarakat terutama yang berkaitan dengan pemasaran berbasis online dan sosial media dengan mengaplikasikan metode antara lain; identifikasi masalah, program pelatihan, program pendampingan, dan program monitoring dan evaluasi. Narasumber utama program ini adalah ahli pemasaran online yang berkolaborasi dengan tim pengabdian yang juga ahli di bidang pemasaran bahkan sudah memiliki bisnis yang sukses. Fokus program ini adalah pemasaran berbasis online dan media sosial untuk produk olahan makanan yang ada di Kelurahan Jabungan. Maka pelatihan ini kami fasilitasi dengan produsen yang terkait dengan produk olahan makanan, salah satunya adalah Madhang.id. Hasil pelatihan menunjukkan bahwa peserta mampu menguasai materi pelatihan dengan baik. Mereka juga mengaplikasikan materi pelatihan tersebut dengan baik dan membuktikan dengan sendiri produk mereka dipajang di Madhang.id.
\end{abstract}

\section{PENDAHULUAN}

Jabungan merupakan salah satu Kelurahan di Kota Semarang yang tepatnya berada di Kecamatan Banyumanik. Secara geografis Kelurahan Jabungan terletak pada $7.0838^{\circ}$ Lintang Selatan - $110.4411^{\circ}$ Bujur Timur. Kelurahan Jabungan berbatasan langsung dengan Desa 
Mluweh dan Desa Kalikayen, Kabupaten Semarang di sebelah selatan dan Kelurahan Meteseh, Kecamatan Tembalang di sebelah timur, serta Kelurahan Kramas Kecamatan Tembalang di sebelah Barat [1, 2, 3]. Topografi yang berbukit-bukit serta jalan yang berkelok-kelok menjadikan jalan menuju Kelurahan Jabungan sedikit menantang namun sangat indah dilihat dan dinikmati.

Berdasarkan survei yang dilakukan oleh tim pengabdian masyarakat pada bulan Januari 2018, diketahui bahwa ternyata Kelurahan Jabungan memiliki potensi yang luar biasa yaitu (1) ditunjuk sebagai kampung tematik empon-empon, (2) memiliki daya tarik wisata Bukit Panji Laras, (3) memiliki potensi produk olahan makanan. Namun permasalahan yang ada di kelurahan ini adalah kurangnya kesadaran pemerintahan desa dan warga, bahwasanya tidak semua orang di luar sana mengenal potensi desa mereka sehingga perlu adanya publikasi pada masyarakat luas.

Publikasi yang paling populer dan sangat digemari saat ini adalah publikasi digital dengan memanfaatkan media yang sudah dimiliki oleh hampir semua orang di dunia yaitu handphone. Dewasa ini, dunia digital sudah masuk pada setiap sektor kehidupan, baik pada pemerintahan maupun masyarakat $[4,5,6]$. Di satu sisi, menghadapi dunia digital memerlukan banyak keterampilan terkait pemanfaatan digital sehingga pemerintah dan masyarakat dapat memanfaatkan teknologi secara bijak, efektif dan efisien. Pemanfaatan teknologi dalam administrasi perkantoran akan memudahkan dalam mengakses informasi, pemetaan data dan pengarsipan data, surat menyurat, maupun pelaporan.

Menghadapi tuntutan tersebut, muncul beberapa permasalahan mitra sebagai berikut: (1) sumber daya manusia dalam penggunaan tekKologi, dalam hal ini adalah literasi digital di Kelurahan Jabungan masih sangat rendah, (2) kelurahan Jabungan belum terkoneksi dengan sosial media sehingga pengelolaan dan pelaporan serta dokumentasi ke masyarakat luas melalui sosial media tidak dapat terlaksana, dan (3) karena potensi Kelurahan Jabungan yang luar biasa, pemerintahan dan masyarakat wajib memiliki kemampuan untuk pemasaran berbasis online dan sosial media.

Setelah mengetahui permasalahan mitra, tim pengabdian menawarkan solusi dengan cara berperan aktif memberikan pelatihan mengenai strategi pemasaran berbasis online dan sosial media untuk meningkatkan sumber daya manusia di Kelurahan Jabungan, Kecamatan Banyumanik, Kota Semarang. Langkah pertama yang dilakukan tim pengabdi adalah pelatihan kepada staf Kelurahan Jabungan sehingga dari sektor pemerintah dapat memanfaatkan teknologi secara bijak, efektif dan efisien. Mereka dapat memanfaatan teknologi dalam administrasi perkantoran yang dapat memudahkan mengakses informasi, pemetaan data dan pengarsipan data, surat menyurat, maupun pelaporan. Selain itu juga dapat dimanfaatkan untuk menyebarkan potensi desa.

Pelatihan tersebut meliputi pemberian pengetahuan mengenai bagaimana memasarkan potensi desa secara online dan di seluruh sosial media yang saat ini sedang berkembang pesat. Bentuk pelatihan yang akan diajarkan berupa ceramah mengenai prosedur operasional pemasaran potensi desa dan mengenalkan sosial media yang paling populer serta mudah dijangkau. Maka kegiatan pengabdian ini bertujuan untuk memberi pengetahuan dan keterampilan kepada staff Kelurahan Jabungan tentang strategi pemasaran berbasis online dan sosial media mengenai produk olahan makanan yang ada di kelurahan Jabungan.

\section{METODE PELAKSANAAN}

Metode yang digunakan untuk mengatasi permasalahan mitra adalah dengan melakukan pendekatan strategis program yang dilakukan dalam beberapa tahap, yaitu: 1) Identifikasi Masalah, 2) Program Pelatihan, 3) Program Pendampingan, 4) Program Monitoring dan Evaluasi. Metode tersebut diterapkan pada pelatihan pemasaran berbasis online dan media sosial kepada 18 staff kelurahan di Kelurahan Jabungan, Kecamatan Banyumanik, Kota Semarang, Jawa Tengah. 


\section{HASIL DAN PEMBAHASAN}

Berdasarkan program kerja dan target tim pengabdian, telah terlaksana keseluruhan rancangan program pelatihan dan pendampingan. Pelatihan ini dilaksanakan selama tiga hari dengan materi pelatihan pada hari pertama yang disampaikan oleh narasumber utama yaitu Bapak Andi Priyolistiyono, S.Kom, M.Kom diikuti oleh nara sumber dari tim pengabdian masyarakat, dilanjutkan pendampingan peserta pada hari berikutnya oleh tim pengabdian dan dibantu oleh mahasiswa, dan diakhiri dengan monitoring dan evaluasi hasil produk peserta pada hari ketiga pelatihan untuk mengetahui hasil pemasaran berbasis online dan sosial media setelah pelatihan dan pendampingan.

Laporan hasil yang dicapai dalam kegiatan ini dijabarkan sebagai berikut:

\section{a. Pelatihan tentang strategi pemasaran berbasis online dan media sosial}

Kegiatan ini merupakan kegiatan yang mengawali rangkaian kegiatan pengabdian masyarakat ini. Dilaksanakan pada hari Minggu, 25 Maret 2018 pukul 08.00 sampai dengan 12.00 berlokasi di aula Kelurahan Jabungan Kecamatan Banyumanik Kota Semarang. Pembukaan dihadiri oleh Kepala Kelurahan Jabungan, Bapak Iriyanto, S.H, Bhabinkantibmas Kelurahan Jabungan, Brigadir Rohadi, S.H., Babinsa Kelurahan Jabungan, Bapak Subur, dan Ketua Karang Taruna, Bapak Luthfi Badrun. Mereka dengan semangat datang di hari Minggu untuk menyambut tim pengabdian dan narasumber utama dengan sangat baik (Gambar 1).
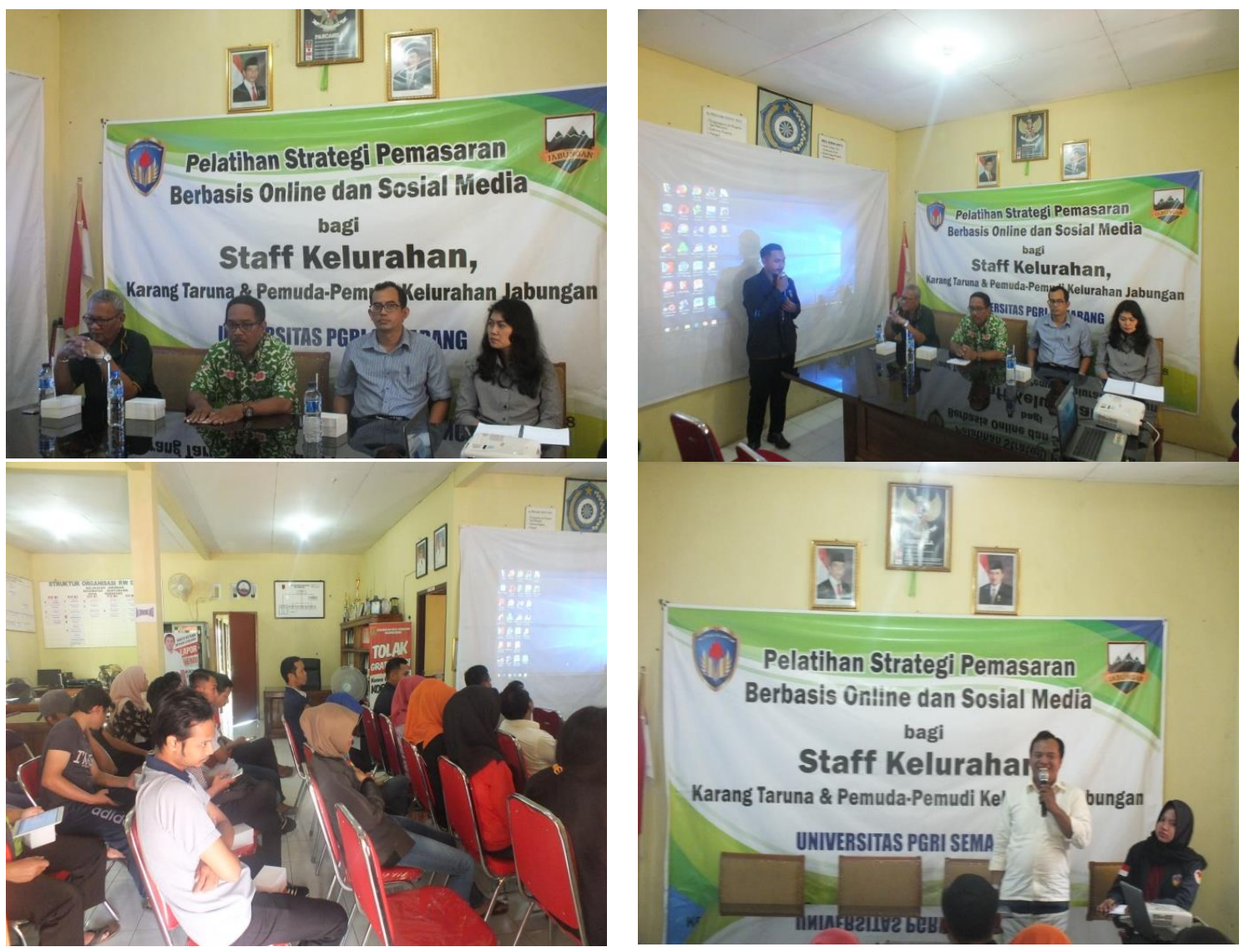

Gambar 1. Foto kegiatan

Dihadiri oleh 18 peserta yang berasal dari staff kelurahan, karang taruna serta pemuda pemudi di lingkungan Kelurahan Jabungan, suasana pelatihan menjadi sangat serius. Bapak Andi Priyolistiyono, S.Kom, M.Kom sebagai nara sumber utama sengaja didatangkan oleh tim dan dipercaya dengan pengalamannya di bidang pemasaran berbasis online dan sosial media mampu menyalurkan ilmu kepada peserta dan menjawab kebingungan peserta. Benar saja, satu jam bersama nara sumber utama, peserta terlihat antusias mengikuti materi beliau mengenai "Insipirasi Pemasaran Daring (Online)".

Materi selanjutnya disampaikan oleh tim pengabdian yaitu Dr. A.B. Prabowo, K.A., S.Pd., M.Hum dan Moch. Fadjar D., S.E., M.Kom mengenai "Bisnis Jaman Now". Materi ini sangat 
tepat disampaikan oleh Bapak Prabowo karena selain dosen beliau juga memiliki bisnis retail yang sudah berjalan bertahun-tahun. Materi berjudul "Pemasaran Digital" yang disampaikan Prof. Dr. Suwandi, M.Pd dan Dra. Siti Lestari, M.Pd pun tidak kalah menarik. Pengalaman Prof. Suwandi dalam membangun bisnis kursus privat di jalan talangsari mampu memperkuat dalam meyakinkan peserta bahwa mereka mampu membangun bisnis mulai dari yang sederhana terlebih dahulu dan nantinya akan menjadi besar seperti bisnis beliau. Materi terakhir yang disampaikan oleh Sukma Nur Ardini, S.S., M.Pd adalah berjudul "Market Place". Nara sumber ini merupakan yang termuda dari nara sumber lainnya. Pengetahuannya tentang bisnis online yang sedang "in" sekarang ini sangat beliau pahami, mulai dari Shopee, JD.ID, Toko Bagus, OLX, dan lain-lain. Demikian juga dengan bagaimana cara mendaftarkan produk ke pusatpusat penjualan online seperti facebook, instagram, dan lain sebagainya. Merangkai kalimat dalam marketing supaya orang tertarik untuk masuk lebih lanjut mengenal produk juga disampaikan nara sumber ini. Pelatihan hari pertama ditutup dengan beberapa pertanyaan dari peserta pelatihan, antara lain:

1. Bagaimana memulai bisnis untuk pertama kali? Apakah kita perlu membidik ke semua market place atau hanya percaya pada satu market place saja? (Ketua Karang Taruna, Bapak Luthfi Badrun)

Jawab: Tidak hanya satu dan tidak semua market place. Bapak wajib membaca review mengenai market place tersebut bagus atau tidak. (Sukma Nur Ardini, S.S., M.Pd)

2. Masakan saya kata orang-orang yang sudah pernah pesan rasanya enak dan saya pengen supaya yang pesan tidak hanya orang sini tapi orang luar. Bagaimana caranya? (Hidayah, pemudi Kel. Jabungan)

Jawab: Ada Madhang app jika produk yang dipasarkan adalah makanan. (Andi Priyolistiyono, S.Kom, M.Kom)

\section{b. Pendampingan Peserta}

Pendampingan ini merupakan pendampingan peserta pelatihan dalam mengaplikasikan hasil pelatihan hari sebelumnya. Fokus kegiatan ini adalah pemasaran berbasis online dan media sosial untuk produk olahan makanan yang ada di Kelurahan Jabungan. Maka pelatihan ini kami fasilitasi dengan produsen yang terkait dengan produk olahan makanan. Salah satunya adalah Madhang.id, yaitu salah satu aplikasi yang mewadahi orang seperti Hidayah (peserta pelatihan yang bertanya mengenai pemasaran masakan) yang ingin menjual masakan buatan rumahan ke masyarakat luas. Selain itu, tim pengabdian dibantu mahasiswa membantu memasang atau men-download aplikasi Madhang serta bagaimana cara mendaftarkan produk mereka di aplikasi tersebut. Pendampingan ini dilakukan tanggal 26 Februari 2018 pukul 12.0016.00 sesuai permintaan peserta sehingga tidak menggangu jam kerja mereka dan tentunya atas izin kepala Kelurahan Jabungan (Gambar 2 dan 3).
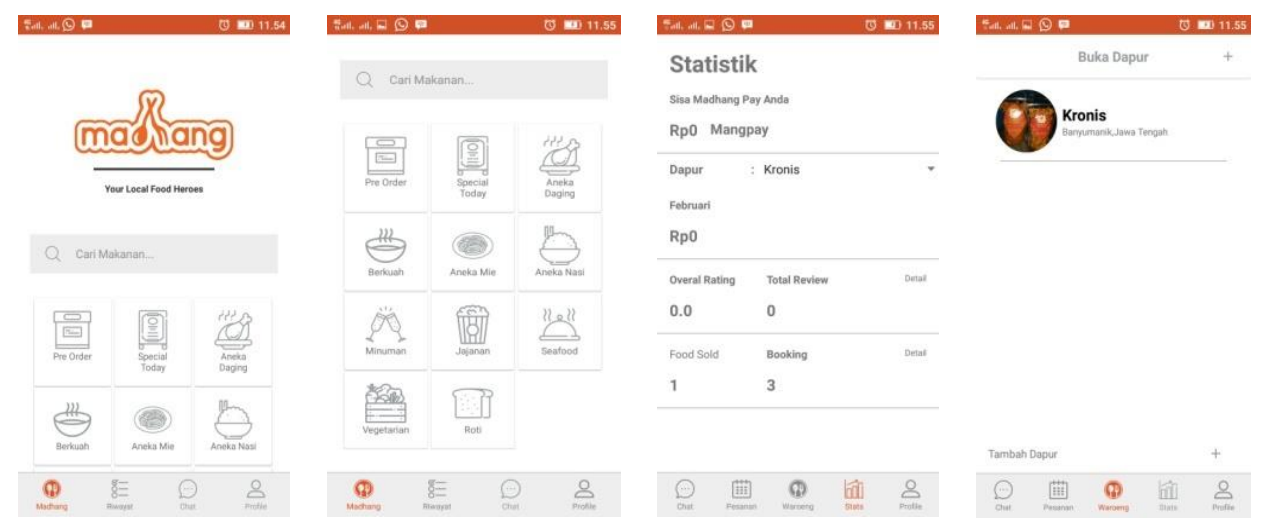

Gambar 2. Proses Pendaftaran Aplikasi 


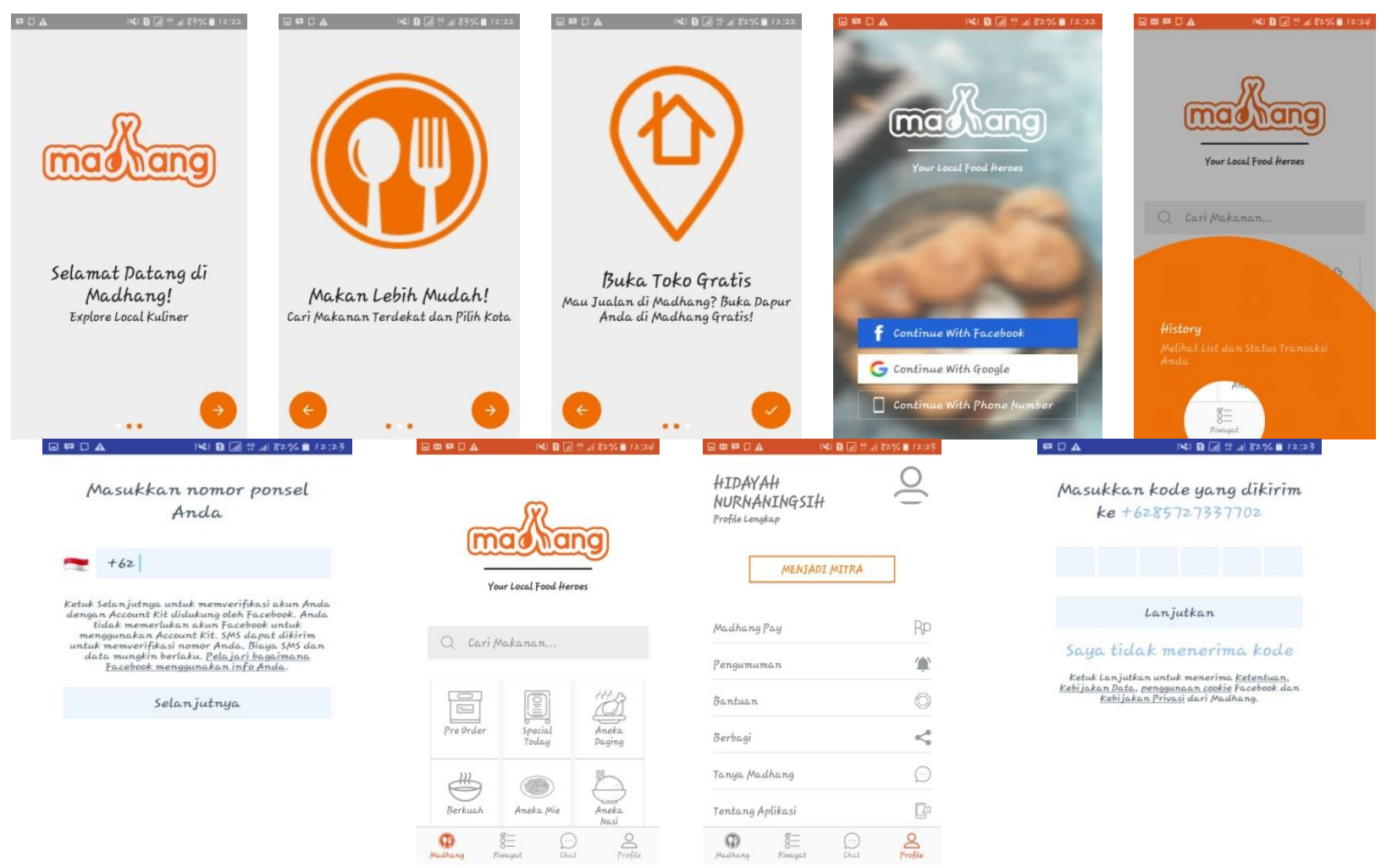

Gambar 3. Proses Pembuatan Aplikasi

\section{c. Monitoring dan Evaluasi}

Tahap terakhir dari kegiatan pengabdian ini adalah monitoring dan evaluasi yang dilaksanakan hari Sabtu, 3 Maret 2018 pukul 12.00-16.00 dengan agenda monitoring dan evaluasi hasil produk peserta. Tim pengabdian dibantu oleh mahasiswa melakukan monitoring dan evaluasi kepada peserta yang telah berhasil memiliki aplikasi Madhang.id di handphone mereka masing-masing. Nama peserta tersebut adalah Hidayah, Sri S, Fadhil dan Badrun. Hasil aplikasi beberapa peserta ditunjukkan seperti pada Gambar 4.

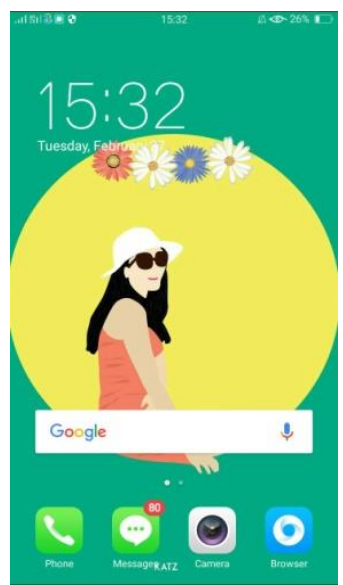

(a)

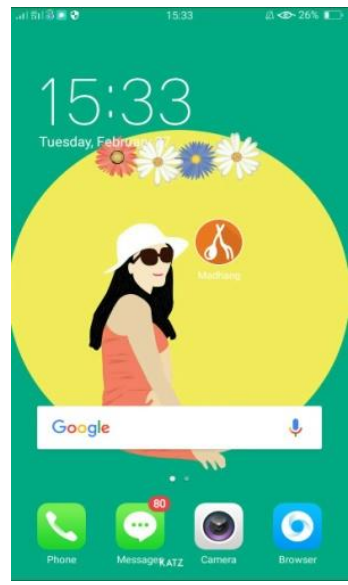

(b)

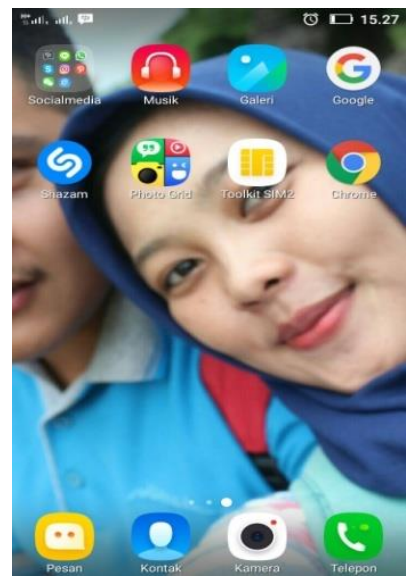

(c)

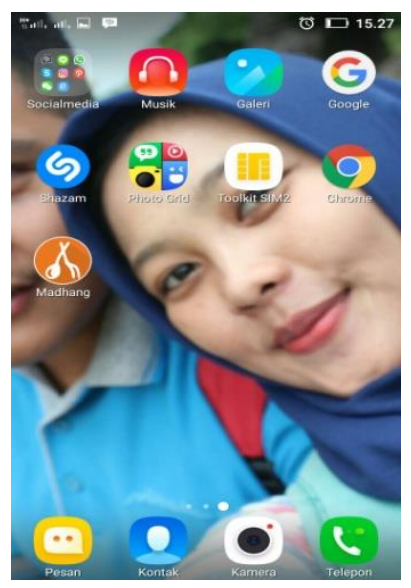

(d)

Gambar 4. (a) Handphone Sri sebelum pelatihan, (b) Handphone Sri setelah pelatihan, (c) Handphone Hidayah sebelum pelatihan, dan (d) Handphone Hidayah setelah pelatihan

\section{KESIMPULAN}

Pelatihan strategi pemasaran berbasis online dan sosial media di Kelurahan Jabungan Kecamatan Banyumanik Kota Semarang dilaksanakan selama tiga hari yang meliputi pelatihan, pendampingan, monitoring dan evaluasi. Fokus pelatihan ini adalah pemasaran hasil produk olahan makanan yang dimiliki oleh Kelurahan Jabungan. Hasil pelatihan menunjukkan bahwa 
peserta mampu menguasai materi pelatihan dengan baik. Mereka juga mengaplikasikan materi pelatihan tersebut dengan baik dan membuktikan dengan sendiri produk mereka dipajang di Madhang.id.

Berdasarkan kesimpulan di atas disarankan bahwa masih perlu adanya pendampingan baik untuk sektor pemerintah maupun masyarakat sehingga tidak hanya produk olahan makanan namun potensi wisata desa dan kampung tematik empon-empon dapat dikenal oleh masyarakat luas mengingat potensi Kelurahan Jabungan yang luar biasa, serta perlu pengembangan fasilitas desa terkait koneksi internet.

\section{DAFTAR PUSTAKA}

[1] Bappeda. 2016. Statistik Kecamatan Banyumanik 2015. Kerjasama Bappeda Kota Semarang \& Badan Pusat Statistik Kota Semarang.

[2] Abdul Kadir. 2012. Pengantar Teknologi Informasi. Yogyakarta: Andi.

[3] Barthos. Basir. 2005. Manajemen Kearsipan. Jakarta: Bumi Aksara.

[4] Awareness. 2008b. Social media marketing: Integrating social media in your marketing mix. http://www.awarenessnetworks.com/resources/Integrating- SocialMedia.pdf.

[5] Boulton, Mark. 2009. A Practical Guide to Designing for the Web. Mark Boulton Design.

[6] Sugiarto. Agus. 2014. Manajemen Kearsipan Elektronik Panduan Pengembangan Aplikasi Kearsipan Elektronik. Yogyakarta: Gava Media. 